\title{
Molecular factors involved in the development of diabetic foot syndrome
}

\author{
Bożena Bruhn-Olszewska1, Anna Korzon-Burakowska², Magdalena Gabig-Cimińska1,3, \\ Paweł Olszewski ${ }^{4}$ Alicja Węgrzyn ${ }^{5}$ and Joanna Jakóbkiewicz-Banecka ${ }^{1 凶}$
}

'Department of Molecular Biology, University of Gdansk, Gdańsk, Poland; 2Department of Diabetology and Hypertension, Medical University of Gdańsk, Gdańsk, Poland; ${ }^{2}$ Laboratory of Molecular Biology (affiliated with the University of Gdańsk), Institute of Biochemistry and Biophysics, Polish Academy of Sciences, Gdańsk, Poland; ${ }^{4}$ Centre for mRNP Biogenesis and Metabolism, Department of Molecular Biology and Genetics, Aarhus University, Aarhus, Denmark; ${ }^{5}$ Department of Microbiology, University of Szczecin, Szczecin, Poland

\begin{abstract}
Diabetes is one of the major challenges of modern medicine, as it is considered a global epidemic of the XXI century. The disease often leads to the development of serious, health threatening complications. Diabetic foot syndrome is a characteristic set of anatomical and molecular changes. At the macroscopic level, major symptoms are neuropathy, ischemia and chronic ulceration of the lower limb. In every third patient, the neuropathy develops into Charcot neuroarthropathy characterized by bone and joints deformation. Interestingly, all these complications are a result of impaired healing processes and are characteristic for diabetes. The specificity of these symptoms comes from impaired molecular mechanisms observed in type 1 and type 2 diabetes. Decreased wound and fracture healing reflect gene expression, cellular response, cell functioning and general metabolism. Here we present a comprehensive literature update on the molecular factors contributing to diabetic foot syndrome.
\end{abstract}

Key words: Diabetic foot syndrome, Charcot neuroartropathy, molecular mechanisms, bone metabolism

Received: 18 November, 2012; revised: 05 December, 2012; accepted: 12 December, 2012; available on-line: 18 December, 2012

\section{INTRODUCTION}

Diabetes is one of the most deceitful diseases that affect more than 346 million people in the world (WHO organization 2012). Not only is the disease itself dangerous but it leads to many complications, like vascular damage and retinopathy (Pirola et al., 2010). The incidence of these complications increases with age and duration of diabetes. Of all diabetic complications, diabetic foot is one of the most devastating and costly (Cornell \& Dorsey, 2012). It develops as a result of neuropathy and ischemia. The risk of foot ulceration development as a consequence of above pathologies is as high as $25 \%$ (Singh et al., 2005).

One of the outcomes of neuropathy is the development of insensitive foot, which increases the risk of ulceration. Degeneration of sensory innervation leads to insensitivity to pain caused by ulcers, wounds, or infections, which are the major causes of limb loss. Diabetic foot syndrome also includes Charcot arthropathy, which is a relatively rare complication of diabetes but studies report incidence of $0.15 \%$ up to nearly $2.5 \%$ (Gupta \& Mohan, 2003; Vasquez \& Henderson, 2010). It occurs in patients diagnosed with deep damage to the peripheral nervous system and intact circulation in the feet. It is believed that in the group of patients with neuropathy, about $16 \%$ may develop neuroarthropathy (Cavanagh et al., 1994). Due to the lack of specific markers and a non-specific clinical picture of Charcot osteoarthropathy, as many as $25 \%$ of cases can be missed or the diagnosis may be delayed (Frykberg \& Belczyk, 2008). Late diagnosis and lack of treatment may result in irreversible deformity of the foot, which is then prone to ulceration, infection and consequently may require amputation. Because of the limited treatment availability and serious consequences, diabetic foot syndrome is becoming an important issue. In the current review, we focused on the molecular basis of the diabetic foot syndrome. Our aim was to gather information about the factors that contribute to chronic ulceration and bone degeneration, and their function in the context of diabetes.

\section{PATHOGENESIS OF NEUROPATHY}

The mechanism behind the development of the diabetic neuropathy is complicated. However, angiopathy and hyperglycemia-induced metabolic changes play the major role. Long-term hyperglycemia causes metabolic disorders which further lead to activation of additional glucose metabolism pathways, in particular the polyol pathway (Yagihashi et al., 2007). Severe changes

e-mail: joannaj@biotech.ug.edu.pl

Abbreviations: AGEs, advanced glycation end products; AGF, angiopoietin-related growth factor (angiogenesis factor); CGRP, calcitonin gene related peptide; CTGF, connective tissue growth factor; DCCT, Diabetes Control and Complications Trial; ECM, extracellular matrix; EGF, epidermal growth factor; FGF, fibroblast growth factor; HB-EGF, heparin-binding EGF-like growth factor; HSP, heat shock protein; HUVEC, human umbilical vein endothelial cells; ICAM-1, intercellular adhesion molecule 1; IGF, insulin-like growth factor; IGFBP, insulin-like growth factor (IGF)-binding protein; IL, interleukin; IRAK-1, interleukin-1 receptor-associated kinase; KGF, keratinocyte growth factor; $\mathrm{M}-\mathrm{CSF}$, macrophage colony-stimulating factor; miR-146a, microRNA 146a; miR-221, microRNA 221; MMP, matrix metalloproteinase; NF-KB, nuclear factor kappa-light-chainenhancer of activated B cells; NGF, nerve growth factor; NOS, nitric oxide synthase; NT-3, neurotrophin-3; OPG, osteoprotegerin; PDGF, platelet derived growth factor; RANK, receptor activator of nuclear factor $\mathrm{K} \mathrm{B}$; RANKL, receptor activator of nuclear factor $\mathrm{K} B$ ligand; SDF-1a, stromal-derived factor-1a; TGF- $\beta$, transforming growth factor $\beta$; TIMPs, tissue inhibitors of metalloproteinases; TNF-a, tumor necrosis factor alfa; TRAF6, TNF receptor-associated factor 6 , E3 ubiquitin protein ligase; TRAIL, TNF-related apoptosis-inducing ligand; VEGF, vascular endothelial growth factor; WHO, world health organization. 
in the polyol pathway lead to an increased accumulation of sorbitol in cells of nervous tissue. Sorbitol is an intermediate product of the glucose-fructose conversion. The reaction is catalyzed by the enzyme aldose reductase. Initially, glucose is reduced to sorbitol and sorbitol is then oxidized to fructose. In hyperglycemia, this process is intensified leading to accumulation of sorbitol in axons, followed by cellular water influx, swelling and Schwann cell damage (Yagihashi et al., 2007; Prashanth et al., 2010). Apart of the direct effect on nervous tissue, chronic hyperglycemia is correlated with vascular damage (Turner, 1998). Increased blood sugar levels may lead to epithelial cell dysfunction, which results in a decrease of pro-angiogenic signaling and production of nitric oxide (NO) (Lusis, 2000). NO additionally causes relaxation of smooth muscle, and its absence decreases vasodilatation, in consequence impairing blood supply to the nerve (Parashanth et al., 2010). Neuropathy in diabetes is correlated with cardiovascular damage not only resulting from metabolic defects, but caused by other risk factors such as hypertension, hyperlipidemia, obesity and cigarette smoking (Tesfaye et al., 2005). Moreover, micro and macroangiopathy have been identified as risk factors in type 2 diabetes mortality. Interestingly, microangiopathy is associated with poor glycemic control, and can develop as a consequence of hyperglycemia (Forsblom et al., 1998).

\section{PHASES OF WOUND HEALING}

The major reason for the limb amputation in diabetes is a high risk of sepsis. Infections develop due to chronic, non-healing wounds and ulcers (Bartus et al., 2004). To date, apart from the general diabetes care, the medical treatment of diabetic foot focuses mostly on proper wound treatment, with attention to regeneration enhancement, and fighting infections (Lipsky et al., 2012; Apelqvist, 2012). In the diabetic foot, the wound healing process is impaired or inhibited, which results in anatomical changes (Lobmann et al., 2005). Non-healing wounds may accelerate morbidity and mortality ( $\mathrm{Xu}$ et al., 2012). The wound healing process depends on the general health of the patient, the location of the wound, age and accompanying diseases such as diabetes (Lobmann et al., 2005). The proper wound repair progresses through a number of ordered events. It is initiated by restoration of 1) hemostasis, followed by clot formation, 2) inflammation, 3) migration and cell proliferation determined by angiogenesis, granulation, tissue formation, epithelization and wound contraction, 4) cutaneous tissue remodeling (Blaktyny et al., 2006; Gethin, 2007; Guo \& DiPietro, 2010).

\section{NORMAL WOUND HEALING PROCESS}

In general, wound healing depends on an interplay between different cell types and their contact mediated by soluble chemicals and hormones. In the wound site, platelets accumulate and aggregate, subsequently producing different growth factors responsible for the formation of the clot and matrix. Production of thrombin which initiates transformation of fibrinogen to fibrin, leads to the formation of a mesh stabilizing platelets at the site of injury. In addition, cytokines and growth factors permeabilize blood vessels, allowing for migration of leukocytes (Blaktyny et al., 2006). The leukocytes are attracted to the injured area by products of the decomposition of collagen and elastin, as well as cytokines TGF- $\beta$, TNF- $\alpha$, interleukin-1 (IL-1) and platelet factor IV (Monaco et al., 2003). Accompanying neutrophils and macrophages remove contaminating bacteria and other foreign factors present at the wound site. Both neutrophils and macrophages release growth factors which initiate the formation of the tissue structure (platelet derived growth factor-PDGF and vascular endothelial growth factor-VEGF). Macrophages are responsible for releasing angiogenesis factor (AGF), which stimulates formation of new blood vessels. The processes of cell migration and proliferation are modulated by various factors, including epidermal growth factor (EGF) and keratinocyte growth factor (KGFalso known as FGF). Cell migration may also require the secretion of matrix metalloproteinases (MMP). This is necessary for partial degradation of the clot and the extracellular matrix (ECM) at the wound site. Partial digestion of the extracellular matrix forms space for the migrating cells. This process is tightly regulated and a balance between degradation and formation of new tissue has to be maintained (Madlener et al., 1998). On the other hand, collagen synthesis rebuilds the tissue and is stimulated by TGF (transforming growth factor), PDGF (platelet derived growth factor), and EGF (epidermal growth factor). Wound contraction, which is the last stage of the healing process, is an effect of the activity of mesenchymal cells (Blaktyny et al., 2006).

\section{WOUND HEALING IN DIABETES}

In diabetes, it has been observed that all stages of wound healing are affected in diabetic foot syndrome. This leads to a specific picture of diabetic wound, which is a hallmark of diabetic foot syndrome. It has been shown that a large number of growth factors, cytokines and chemokines, which are released by keratinocytes, fibroblasts, endothelial cells, macrophages and platelets, have their serum levels changed in diabetes. These factors are responsible for initiating the wound repair process and its maintenance, which results in gradual decrease in inflammatory response (Eubank \& Marsh, 2010; Blaktyny et al., 2006). Diabetic wounds are characterized by a reduced level of the following growth factors and receptors: KGF (keratinocyte growth factor), TGF- $\beta 1$ (transforming growth factor beta), NGF (nerve growth factor), PDGF, VEGF, IL-8, IL-10, IL-15, neurotrophin-3 (NT-3), substance P, CGRP (Blaktyny et al., 2009). Selected factors are described in Table 1. Decreased levels of these important growth factors might contribute to poor tissue regeneration and impaired wound healing.

\section{EFFECTS OF TGF- $\beta 1$ DEFICIENCY}

Deficiency of TGF- $\beta 1$ in chronic wounds may contribute to the increased level and activity of nitric oxide synthase (NOS). The enzyme produces nitric oxide (NO) which is a signal molecule with biological activity. The effects of NO signaling vary in different cell types and tissues. In general, it causes relaxation of smooth muscle, what leads to increased blood flow in blood vessels. However, during wound healing the contraction of blood vessel helps to prevent bleeding, thus NO action early during healing is unfavorable. Additionally its action is associated with prevention of platelet aggregation and leukocyte adhesion (Riddel \& Owen, 1999). It is possible that increased levels of NO in the 
plasma are associated with recurrent ulcers in diabetic foot syndrome (Blaktyny et al., 2006; Stojadinovic et al., 2012). The synthesis of NO positively correlates with expression of heat shock proteins (Hsps), while inhibition of the process reduces levels of Hsp (Mayshylev et al., 1995).

Abnormalities in the functioning of the heat shock proteins, which are also observed in diabetes, may lead to impairment of wound healing. In contrast to the increased Hsp levels observed in diabetic patients, rats with chemically induced diabetes show decreased levels of Hsp72 protein in blood. Interestingly, regulation occurs at the protein level since mRNA level is not affected (Bitar et al., 1999; Yamagishi et al.; 2001, Atalay et al., 2009). Current model explains the role of $\mathrm{Hsp} 72$ by its involvement in protein folding as well as in the transport of newly synthesized proteins required for tissue reconstitution (Kruglikov et al., 2011).

\section{WOUND REPAIR THROUGH PROTEOLYSIS}

Cell-to-cell communication is mediated by growth factors and cytokines secreted to the extracellular matrix (ECM). The dynamics of this extracellular environment is modulated by matrix metalloproteinases (MMPs) (McCawley \& Martisan, 2001). These proteolytic enzymes are zinc-dependent endopeptidases (Maskos, 2004) Substrates for MMPs include structural elements of ECM (collagen, fibronectin, basal membrane), cell membrane receptors (CD44, ICAM-1, IGFBP) and growth factors precursors (pro-TNF $\alpha$ and precursor of TGF $\beta$ ) (Nagase et al., 2006). Interestingly, mature forms of growth factors (CTGF and HB-EGF) and cytokines (RANKL and IL-1 $\beta$ ) can also be substrates (Hao et al., 2003; Hashimoto et al., 2002; Zhang et al., 2003). Importantly, proteolysis may lead to activation or solubilization by release from ECM, as well as to degradation of the substrate (Visse \& Nagase 2003, Nagase et al., 2006). It has been demonstrated that most MMP-encoding genes have a TGF- $\beta 1$-dependent inhibitory element in the promoter region, which downregulates the gene's expression. Decreased levels of TGF- $\beta 1$ lead to overexpression of MMPs, which results in excessive digestion of the growth factors. However, the molecular details of MMPs overexpression in diabetes are still not known (Stojadinovic et al., 2012). MMPs activity is modulated by tissue inhibitors of metalloproteinases (TIMPs), represented by four isoforms (Brew et al., 2000). These inhibitors enable tight regulation of protease activity preventing tissue destruction. This physiological balance between MMPs and their specific TIMPs is disrupted in diabetes (Lobmann et al., 2002; Stojadinovic et al., 2012). Several studies have shown a high concentration of MMP9 in wound liquid and a high ratio of MMP9 to TIMP-1 portends poor healing of diabetic foot ulcers (Ladwig et al., 2002; Liu et al., 2009).

The aspartic endopeptidase cathepsin D plays an important role in cell growth, proteolytic degradation, cell invasion and apoptosis (Beaujouin et al., 2006). Study in rats with streptozotocin-induced diabetes showed increased proteolytic degradation of collagen in wounds (Pałka et al., 1991). This effect was reversed by external application of a cathepsin D inhibitor, suggesting that this was the main enzyme responsible for collagen decomposition. Interestingly, patients with ulcerated diabetic foot had increased plasma levels of cathepsin D, which can contribute to poor wound healing (Ahmad et al., 2012).

\section{CYTOKINES INVOLVED IN WOUND HEALING}

Cytokines are small proteins, soluble in the serum and interacting with cell surface receptors. They serve as a communication network between cells. By interaction with specific transmembrane receptor, they activate signal cascade, which result in cellular response (Nicholson et al., 2004).

Insuline-like growth factor (IGF) is a complex of two peptides: IGF-1 and IGF-2 (Jonathan et al., 2004). IGF-1 is a cytokine that participates in cell granulation during wound healing. During this process, expression of IGF-1 is increased. Interestingly, in diabetic patients expression of IGF-1 is decreased which may explain cell granulation defects ( $\mathrm{Yu}$ et al., 2007; Blaktyny et al., 2005). It was found that IGF-1 is crucial in the regulation of the synthesis of Hif- $1 \alpha$ protein during wound healing. The reduced level of IGF observed in diabetes may explain low levels of Hif-1a protein ( $\mathrm{Yu}$ et al., 2007). Importantly, Hif- $1 \alpha$ is an angiogenesis-promoting factor. It controls expression of several downstream factors involved in angiogenesis. Decreased levels of Hif- $1 \alpha$ observed in diabetic mice and diabetic foot ulcers (Catrina et al., 2004; Botusan et al., 2008) can be one of the major reasons of poor blood vessel formation in diabetic foot. IGF-2 plays a key role in the development of the embryo and fetus. Shao and colleagues (2008) found that in fetuses of mice with induced diabetes, IGF-2 mRNA levels were reduced almost by half comparing with controls. It is possible that reduced level of IGF-2 is also associated with acute diabetes, since it is responsible for the development of pancreatic beta cells.

The process of wound healing in diabetic patients is also associated with a decreased level of expression of SDF- $1 \alpha$. Inhibition of SDF- $1 \alpha$ activity leads to a reduction of the number of CD31+ cells which finally contributes to the much slower wound repair (Bermudez et al., 2011). CD31 is one of the markers analyzed in angiogenesis. It is a glycoprotein present on the surface of endothelial cells, monocytes, granulocytes and platelets (Scelsi et al., 2005). SDF-1 $\alpha$ activity is the most important at early steps of wound healing, since its overexpression increases the healing rate (Badillo et al., 2007).

Analysis of skin biopsies at the molecular level reveals pathogenic markers that are associated with delayed wound healing. These include primarily an increased level of c-Myc. Its expression is activated by $\beta$-catenin, which is involved in the inhibition of keratinocyte migration, and EGF response (Stojadinovic et al., 2005).

Recent studies indicate a relationship between markers of inflammation IL-6, IL-8, IGF-1 levels and microvascular changes in the same group of patients with type I diabetes. Studies show that the level of IGF-1 is decreased in respect to control group and this is linked with increased levels of IL-6 and IL-8 in young people with type I diabetes (Abo El Asrar et al., 2012).

A very important factor that affects the inflammatory response is micro RNA miR-146a. This small non-coding RNA serves as a negative feedback regulator of IRAK1 and TRAF6 expression (Hou et al., 2009). IRAK1 and TRAF6 are elements of intracellular signal conducting cascade, and are associated with transmembrane receptors, including RANKL/RANK (Gohda et al., 2005). It has been shown that the miR-146a expression is significantly reduced in the wound in people diagnosed with diabetes. This correlates with an increased expression of its target genes IRAK1 and TRAF6, as well as related elements of the signaling cascade of NF- $x \mathrm{~B}$, IL-6 and MP-2 (Xu et al., 2012). This situation leads to enhanced 
Table 1. Molecular factors involved in diabetic foot syndrome formation

\begin{tabular}{|c|c|c|c|}
\hline Factor & Status in diabetes & Effect & Reference \\
\hline PDGF & decreased & $\begin{array}{l}\text { decreased upon fracture healing, possible defects in general } \\
\text { wound healing }\end{array}$ & Tyndal et al., 2003 \\
\hline KGF & decreased & healing rate decreased & Werner et al.,1994 \\
\hline VEGF & decreased & healing rate decreased & $\begin{array}{l}\text { Frank et al., } 1995, \\
\text { Bitto et al., } 2008\end{array}$ \\
\hline $\begin{array}{l}\text { IL-6 } \\
\text { IL-8 }\end{array}$ & increased & enhanced immune response, sustained inflammation state & Abo El Asrar et al., 2012 \\
\hline $\lg -2$ & decreased & $\begin{array}{l}\text { decrease observed in diabetic mice fetuses, possible implications } \\
\text { in pancreatic cell development }\end{array}$ & Shao et al., 2008 \\
\hline $\lg -1$ & decreased & cell granulation defects & $\begin{array}{l}\text { Yu et al., 2007, } \\
\text { Blaktyny et al., } 2005\end{array}$ \\
\hline mir-146 & decreased & enhanced immune response and sustained inflammation state & Xu et al., 2012 \\
\hline SDF1-a & decreased & slower healing rate, defects in angiogenesis & $\begin{array}{l}\text { Badillo et al., 2007, } \\
\text { Bermudez et al., } 2011\end{array}$ \\
\hline c-Myc & increased & $\begin{array}{l}\text { possible marker of B-catenin hyperactivation, resulting in inhibi- } \\
\text { tion of keratinocyte migration and EGF response }\end{array}$ & Stojadinovic et al., 2005 \\
\hline Hif1-a & decreased & possible defects in angiogenesis & $\begin{array}{l}\text { Catrina et al., 2004, } \\
\text { Botusan et al., } 2008\end{array}$ \\
\hline RANKL & increased & disturbed RANKL/OPG ratio, possible increased bone resorption & de Amorin et al., 2008 \\
\hline TNFa & increased in wounds & enhanced fibroblasts apoptosis & Siqueira et al., 2010 \\
\hline TNFa & & & \\
\hline TRAIL & decreased in fractures & $\begin{array}{l}\text { increased osteoclast activation and bone resorption and cartila- } \\
\text { ge removal }\end{array}$ & $\begin{array}{l}\text { Kayal et al., 2007; } \\
\text { Kayal et al., } 2009\end{array}$ \\
\hline MCF & & & \\
\hline cathepsin D & increased & abnormal collagen decomposition & Ahmad et al., 2012 \\
\hline MMP-9 & increased & abnormal ECM decomposition, possible TGF1 $\beta$ degradation & $\begin{array}{l}\text { Ladwig et al., 2002; } \\
\text { Liu et al., } 2009\end{array}$ \\
\hline
\end{tabular}

inflammatory response, and can be a reason for chronic inflammation related to diabetes. Interestingly, treatment of wounds with mesenchymal stem cells reduces inflammation and accelerates wound healing. The treatment results in increased expression of miR-146a in the surrounding tissue, thus expression of miR-146a may depend on an extracellular signal (Xu et al., 2012).

\section{FACTORS INVOLVED IN FRACTURE HEALING AND BONE REMODELING IN DIABETES}

The disease process in diabetic foot syndrome can lead to severe destruction of bone structures. The cause of these changes is not clear. Diabetes may cause a net loss of bone due to the strong suppression of bone formation and accelerated bone resorption ( $\mathrm{Lu}$ et al., 2003; Vestergaard et al., 2007). An increased bone-loss rate leads to development of osteopenia. It is characterized by the reduction of the mass of bone tissue, while retaining correct mineralization (Duarte et al., 2005).

It has been demonstrated that the molecular triad OPG/RANKL/RANK plays a major part in many bone-related diseases (Boyce et al., 2008). Osteoprotegerin (OPG) is a glycoprotein receptor from the family of tumor necrosis factor (TNF) produced in many organs of the body, including osteoblasts (Loris et al., 2001). It is present in a soluble form in the blood serum where its major role is capturing the excess of RANK ligand (RANKL). RANK protein is expressed in osteoclasts and their precursors. It is a membrane-anchored receptor present on the cell surface (Santini et al., 2011). RANKL is expressed mainly in bone and $\mathrm{T}$ cells, and plays an important role in the activation of osteoclasts (Santini et al., 2011; Boyce et al., 2008). RANKL binding to RANK receptor initiates a signal cascade mediated by TRAF6, leading to the activation and differentiation of the osteoclast which results in bone resorption. The effects of the interaction between RANKL and RANK are physiologically counterbalanced by OPG, which acts as a soluble receptor for RANKL and thus prevents the RANKL-RANK interaction. Any change in the ratio of RANKL to OPG may be critical in the control of the bone and skeletal system metabolism (Boyle et al., 2003).

It has been previously demonstrated in humans and in animal models that fracture healing in diabetes is much slower than in non-diabetic controls (de Amorin et al., 2008; Duarte et al., 2007; Diniz et al., 2008; Vestergaard et al., 2005). De Amorin and collegues (2008) studied bone remodeling in rats with alloxan-induced diabetes. Their results showed that 14 days after fracture expression of RANK, RANKL and OPG was reduced at fracture sites. However, the ratio of RANKL to OPG was clearly higher in the diabetic group, which may indicate increased bone resorption.

It was found that in rodents with type I diabetes the content of protein and minerals in the extracellular ma- 
trix is reduced (Gandhi et al., 2006). It includes collagen, proteoglycan (PG), osteocalcin, calcium and magnesium. Additionally, the level of growth factors responsible for stimulating bone and cartilage formation IGF-1, PDGF, TGF-31, basic fibroblast growth factor (bFGF), and VEGF is decreased. All these factors are essential for proper wound and bone healing, and their functional impairment is common in diabetes in humans (Bennett et al., 2003, Blaktyny et al., 2009).

Many factors that are specifically associated with osteoclast formation such as RANK, RANKL, tumor necrosis factor $\alpha(\mathrm{TNF} \alpha)$, TNF-related apoptosis-inducing ligand (TRAIL) and macrophage colony-stimulating growth factor (M-CSF) are upregulated in diabetic mice. This correlates with increased number of osteoclasts in tissues, resulting in increased bone and cartilage removal (Kayal et al., 2007; Kayal et al., 2009).

In the past few years, several studies have suggested that OPG and RANKL are linked with Charcot arthropathy (Jeffcoate, 2005; Mabilleau et al., 2008). It is a chronic disease characterized by progressive bone and joint destruction of the lower limbs. Symptoms are relatively painless due to a loss of the sensory innervation. The most characteristic symptoms include pathological fractures, joint dislocation, and deformations (Rogers et al., 2011). The majority of patients with Charcot neuroarthropathy are between 50 and 60 years old, and most of them have been suffering from diabetes for at least 10 years (Rajbhandari et al., 2002). A common feature of Charcot neuroarthropathy is increased bone reabsorption. It is most likely caused by increased activity of osteoclasts, which may lead to osteopenia (Pitocco et al., 2009). Additional evidence for a role of the molecular triad in Charcot neuroarthropathy development comes from genetic studies. It has been shown that selected polymorphisms in the opg gene occur more often in patients with diagnosed neuroarthropathy (Korzon-Burakowska et al., 2012).

Increased blood sugar levels in diabetics can lead to the formation of advanced glycation end products (AGEs) (Duarte et al., 2007), which are associated with delayed bone healing in these patients. Moreover, in diabetics this process may be escalated by the intensity of oxidative stress and the increased glucose levels (Santana et al., 2003). These conditions favor non-enzymatic glycation of proteins like hemoglobin, albumin, collagen and crystalline (Jabłońska-Trypuć, 2007). It is known that the accumulation of AGEs induces complicated changes in microdamage mechanism of bone (Tang et al., 2010) and leads to reduced mechanical strength of bone, which may cause fracture.

\section{EPIGENETICS OF THE DIABETIC FOOT SYNDROME}

Genetic mutations in factors directly involved in the diabetic foot syndrome are not solely responsible for the disease development. An increasing number of studies indicate the importance of epigenetic mechanisms in diabetes. Epigenetic changes are very diverse and include post-translational modifications of histones, methylation of cytosine in DNA, mitochondrial inheritance, microRNA expression, as well as transposable elements (Slotkin \& Martienssen, 2007; Goldberg et al., 2007; Kim et al., 2009). These changes affect gene expression without changes in genomic DNA sequence. DNA methylation as the basis of genetic imprinting is a process of inactivation of one gene allele, depending on the methylation pattern inherited from one of the parents. In consequence, only one copy of the gene is active. As an example, the IGF-
2 gene is expressed only from the paternal allele (DeChiara et al., 1991). Large-scale studies of inherited methylation patterns and their association with disease identify several sites associated with type 2 diabetes (Kong et al., 2009). Among these, the most relevant is the KCNQ1 locus, which has been associated with mono- and polygenic diabetes in humans (Yasuda et al., 2008; Unoki et al., 2008). Interestingly, DNA methylation patterns can also change in response to environmental stimuli. The process is termed metabolic memory, and is defined by changes of genes expression in cells exposed to various stress conditions (Pirola et al., 2010). It has been shown that methylation of adiponectin gene in the placenta results in elevated protein levels in mother's blood, and is inversely correlated with the mother's blood sugar levels (Bouchard et al., 2012). It is known that hyperglycemia is the most important factor contributing to diabetes-related complications, as revealed by large-scale, long-term studies DCCT and EDIC (Diabetes Control and Complication Trial 1993) (Nathan et al., 2005; Pop-Busui et al., 2009). In addition to the human studies, there is a number of animal studies (Engerman et al., 1987; Hammes et al., 1993; Kowluru et al., 2003) and in vitro cell culture studies (Roy et al., 1990; Ihnat et al., 2007) supporting the metabolic memory hypothesis. Especially a study performed by El Osta and colleagues (2008) shows changes in histone methylation in the RELA promoter region induced by hyperglycemia and maintained after restoring non-glycemic conditions. This kind of epigenetic mechanism might contribute to the overall picture of diabetic foot syndrome, changing expression of genes required for proper wound healing (Rafehi et al., 2012). However, despite numerous studies, there is no data about methylation patterns during wound healing process, or relation with diabetic foot syndrome. There are, however, several examples of micro RNA-mediated changes in gene expression (Madhyastha et al., 2011; Caporali et al., 2011). Some information can be obtained from in vitro studies on vascular epithelial cells (Li et al., 2009). Indeed, performed experiments show increased miR-221 RNA expression in HUVEC cells upon high glucose treatment. Treatment with miR-221 antisense RNA abolished the overexpression and restored the migration ability of the cells, which was previously impaired. However, the fact that epigenetic modifications can be induced metabolically argues for animal model studies. An interesting model for an epigenetic mechanism involved in neuropathy development comes from a study on HIVassociated-sensory neuropathy (HIV-SN) (Lehmann et al., 2011). HIV-SN is among the most frequent complications of HIV infection. It is characterized by a progressive anaesthesia starting in the feet (Cornblath et al., 1988). Interestingly, this neuropathy is caused by a deletion in the mitochondrial genome, leading to mitochondrial dysfunction in distal axons. It is possible that the neuropathy related to diabetic foot has a similar etiology.

\section{SUMMARY}

Diabetic foot syndrome is characterized by abnormalities at the macroscopic, cellular and molecular level. In this article, we reviewed the most important issues concerning cellular response and intracellular mechanisms affecting gene expression in the context of diabetic foot. The importance of the problem is highlighted by the increasing number of detailed studies. Attempts to understand the disease address different aspects of molecular biology, including the most recent findings about gene expression regulation. However, despite those extensive 
studies in the field many questions remain unanswered. Future studies, although challenging, will bring more light into the field of diabetes-related complications, and most likely will result in effective therapies against diabetic foot syndrome.

\section{Acknowledgments}

This work was supported by the Ministry of Science and Higher Education (Poland) (project grant no. $\mathrm{N}$ N402 309936 to A.K-B).

\section{REFERENCES}

Abo El Asrar MA, Elbarbary NS, Elshennawy DE, Omar AM (2012) Insulin-like growth factor-1 cytokines cross-talk in type 1 diabetes mellitus: relationship to microvascular complications and bone mineral density. Cytokine 59: 86-93.

Ahmad J, Zubair M, Malik A, Siddiqui MA, Wangnoo SK (2012) Cathepsin-D, adiponectin, TNF- $\alpha$, IL- 6 and hsCRP plasma levels in subjects with diabetic foot and possible correlation with clinical variables: a multicentric stud. Foot 22: 194-199.

Apelqvist J (2012) Diagnostics and treatment of the diabetic foot. Endocrine 41: 384-397.

Atalay M, Oksala N, Lappalainen J, Laaksonen DE, Sen KCh, Roy S (2009) Heat shock proteins in Diabetes and wound healing. Curr Protein Pept Sci 10: 85-95.

Badillo AT, Chung S, Zhang L, Zoltick P, Liechty KW (2007) Lentiviral gene transfer of SDF-1alpha to wounds improves diabetic wound healing. I Surg Res 143: 35-42.

Bartus CL, Margolis DJ (2004) Reducing the incidence of foot ulceration and amputation in diabetes. Curr Diab Rep 4: 413-418.

Beaujouin M, Baghdiguian S, Glondu-Lassis M, Berchem G, LiaudetCoopman E (2006) Overexpression of both catalytically active and -inactive cathepsin D by cancer cells enhances apoptosis-dependent chemo-sensitivity. Oncogene 25: 1967-1973.

Bermudez DM, Xu J, Herdrich BJ, Radu A, Mitchell ME, Liechty KW (2011) Inhibition of stromal cell-derived factor- $1 \alpha$ further impairs diabetic wound healing. J V asc Surg 53: 774-784.

Bitar MS, Farook T, John B, Francis IM (1999) Heat-shock protein $72 / 73$ and impaired wound healing in diabetic and hypercortisolemic states. Surgery 125: 594-601.

Bitto A, Minutoli L, Galeano MR, Altavilla D, Polito F, Fiumara T, Calò M, Lo Cascio P, Zentilin L, Giacca M, Squadrito F (2008) Angiopoietin-1 gene transfer improves impaired wound healing in genetically diabetic mice without increasing VEGF expression. Clin Sci (Lond) 114: 707-718.

Botusan IR, Sunkari VG, Savu O, Catrina AI, Grunler J, Lindberg S, Pereira T, Yla-Herttuala S, Poellinger L, Brismar K, Catrina SB (2008) Stabilization of HIF-1alpha is critical to improve wound healing in diabetic mice. Proc Natl Acad Sci USA 105: 19426-19431.

Bouchard L, Hivert MF, Guay SP, St-Pierre J, Perron P, Brisson D. (2012) Placental adiponectin gene DNA methylation levels are associated with mothers' blood glucose concentration. Diabetes 61: 1272-1280.

Boyce BF, Xing L (2008) Functions of RANKL/RANK/OPG in bone modeling and remodeling. Arch Biochem Biophys 473: 139-146.

Boyle WJ, Simonet WS, Lacey DL (2003) Osteoclast differentiation and activation. Nature 423: 337-342.

Brew K, Kinakarpandian J, Nagase H (2000) Tissue inhibitors of metalloproteinases: evolution, structure and function. Biochim Biophys Acta 1477: 267-283.

Caporali A, Meloni M, Vollenkle C, Bonci D, Sala-Newby GB, Addis R, Spinetti G, Losa S, Masson R, Baker AH, Agami R, le Sage C, Condorelli G, Madeddu P, Martelli F, Emanueli C (2011) Deregulation of microRNA-503 contributes to diabetes mellitus-induced impairment of endothelial function and reparative angiogenesis after limb ischemia. Circulation 123: 282-291.

Catrina SB, Okamoto K, Pereira T, Brismar K, Poellinger L (2004) Hyperglycemia regulates hypoxia-inducible factor-1alpha protein stability and function. Diabetes 53: 3226-3232.

Cavanagh PR, Young MJ, Adams JE, Vickers KL, Boulton AJ (1994) Radiographic abnormalities in the feet of patients with diabetic neuropathy. Diabetes Care 17: 201-209.

Cornblath DR, McArthur JC (1988) Predominantly sensory neuropathy in patients with AIDS and AIDS-related complex. Neurology 38: 794-796.

Cornell S, DorseyVJ (2012) Diabetes Pharmacotherapy in 2012: Considerations in Medication Selection Postgraduate Med 124: 84-94.

de Amorim FP, Ornelas SS, Diniz SF, Batista AC, da Silva TA (2008) Imbalance of RANK, RANKL and OPG expression during tibial fracture repair in diabetic rats J Mol Histol 39: 401-408.
DeChiara TM, Robertson EJ, Efstratiadis A (1991) Parental imprinting of the mouse insulin-like growth factor II gene. Cell 64: 849-59.

Diniz SF, Amorim FP, Cavalcante-Neto FF, Bocca AL, Batista AC, Simm GE, Silva TA (2008) Alloxan induced diabetes delays repair in a rat model of closed tibial fracture. Braz J Med Biol Res 41: 373379 .

Duarte VM, Ramos AM, Rezende LA, Macedo UB, Brandão-Neto J, Almeida MG, Rezende AA (2005) Osteopenia: a bone disorder associated with diabetes mellitus. J Bone Miner Metab 23: 58-68.

Duarte PM, Neto JB, Casati MZ, Sallum EA, Nociti FH Jr (2007) Diabetes modulates gene expression in the gingival tissues of patients with chronic periodontitis. Oral Dis 13: 594-599.

Engerman RL, Kern TS (1987) Progression of incipient diabetic retinopathy during good glycemic control. Diabetes 36: 808-812.

Eubank TD, Marsh CB (2010) Cytokines and Growth factors in the Regulation of Wound Inflammation. In Advances in Wound Care. Chandon KS, ed, pp 211-216. Mary Ann Liebert Inc. publishers, New York, USA.

Forsblom CM, Sane T, Groop PH, Tötterman KJ, Kallio M, Saloranta C, Laasonen L, Summanen P, Lepäntalo M, Laatikainen L, Matikainen E, Teppo AM,Koskimies S, Groop L' (1998) Risk factors for mortality in Type II (non-insulin-dependent) diabetes: evidence of a role for neuropathy and a protective effect of HLA-DR4. Diabetologia 41: 1253-1262.

Frank S, Hübner G, Breier G, Longaker MT, Greenhalgh DG, Werner S (1995) Regulation of vascular endothelial growth factor expression in cultured keratinocytes. Implications for normal and impaired wound healing. I Biol Chem 270: 12607-12613.

Gandhi A, Doumas C, O'Conner JP, Parsons JR, Lin SS (2006) The effects of local platelet rich plasma delivery on diabetic fracture healing. Bone 38: 540-546.

Gethin $G$ (2007) The significance of surface $\mathrm{pH}$ in chronic wounds. Wounds UK 3: 52-54.

Gohda J, Akiyama T, Koga T, Takayanagi H, Tanaka S, Inoue J (2005) RANK-mediated amplification of TRAF6 signaling leads to NFATc1 induction during osteoclastogensis. EMBO J 24: 790-799

Goldberg AD, Allis CD, Bernstein E. (2007) Epigenetics: a landscape takes shape. Cell 128: 635-638.

Gupta PPK, Mohan V (2003) Charcot Foot - An Update. J Assoc Physicians India 51: 367-72.

Guo S, DiPietro LA (2010) Factor affecting wound healing. J Dent Res 89: 219-229.

Hammes HP, Klinzing I, Wiegand S, Bretzel RG, Cohen AM, Federlin K (1993) Islet transplantation inhibits diabetic retinopathy in the sucrose-fed diabetic Cohen rat. Invest Opbthalmol Vis Sci 34: 2092-2096.

Hao L, Du M, Lopez-Campistrous A, Fernandez-Patron C (2003) Agonist-induced activation of matrix metalloproteinase- 7 promotes vasoconstriction through the epidermal growth factor-receptor pathway. Circ Res 94: 68-76.

Hashimoto G, Inoki I, Fujii Y, Aoki T, Ikeda E, Okada Y (2002) Matrix metalloproteinases cleave connective tissue growth factor and reactivate angiogenic activity of vascular endothelial growth factor 165. J Biol Chem 277: 36288-36295.

Hou J, Wang P, Lin L, Liu X, Ma F, An H, Wang Z and Cao X (2009) MicroRNA-146a feedback inhibits RIG-I-dependent type I IFN production in macrophages by targeting TRAF6, IRAK1 and IRAK2. J Immunol 183: 2150-2158.

Ihnat MA, Thorpe JE, Kamat CD, Szabó C, Green DE, Warnke LA, Lacza Z, Cselenyák A, Ross K, Shakir S, Piconi L, Kaltreider RC, Ceriello A (2007) Reactive oxygen species mediate a cellular 'memory' of high glucose stress signaling Diabetologia. 50: 1523-1531.

Jabłońska-Trypuć A (2007) Molecular mechanism of non-enzymatic glication of proteins and its role in diabetes. Termedia 4: 253-258.

Jeffcoate W (2005) Vascular calcification and osteolysis in diabetic neuropathy - is RANK-L the missing link? Diabetologia 47: 1488-1492.

Kayal RA, Albowi J, McKenzie E, Krothpalli N, Silkman L, Gerstenfeld LC, Einhorn TA, Graves T (2009) Diabetes causes the accelerated loss of cartilage during repair which is reversed by insulin treatment. Bone 44: 357-363.

Kayal RA, Tsatsas D, Bauer MA, Allen B, O AL-Sebaei M, Kakar S, Leone CW, Morgan EF, Gerstenfeld LC, Einhorn TA, Graves DT (2007) Diminished bone formation during diabetic fracture healing is realted to the premature resorption of cartilage associated with increased osteoclast activity. J Bone Miner Res 22: 560-568.

Kim JK, Samaranayake M, Pradhan S (2009) Epigenetic mechanisms in mammals. Cell Mol Life Sci 66: 596-612.

Kong A, Steinthorsdottir V, Masson G, Kong A, Steinthorsdottir V, Masson G, Thorleifsson G, Sulem P, Besenbacher S, Jonasdottir A, Sigurdsson A, Kristinsson KT, Jonasdottir A, Frigge ML Gylfason A, Olason PI, Gudjonsson SA, Sverrisson S, Stacey SN, Sigurgeirsson B, Benediktsdottir KR, Sigurdsson H, Jonsson T, Benediktsson R, Olafsson JH, Johannsson OT, Hreidarsson AB, Sigurdsson G; DIAGRAM Consortium, Ferguson-Smith AC, Gudbjartsson DF, Thorsteinsdottir U, Stefansson K (2009) Parental origin of sequence variants associated with complex diseases. Nature 462: 868-874. 
Korzon-Burakowska A, Jakóbkiewicz-Banecka J, Fiedosiuk A, Petrova N, Koblik T, Gabig-Cimińska M, Edmonds M, Małecki MT, Wegrzyn G (2012) Osteoprotegerin gene polymorphism in diabetic Charcot neuroarthropathy. Diabetic Med 29: 771-775.

Kowluru RA (2003) Effect of reinstitution of good glycemic control on retinal oxidative stress and nitrative stress in diabetic rats. Diabetes 52: 818-823.

Kruglikov I, Kruglikova E (2011) Dual Treatment Strategy by Venous Ulcers: Pilot study to dual-frequency ultrasound application. J Cosmetics Der Sci Appl 1: 157-163.

Ladwig GP, Robson MC, Liu R, Kuhn MA, Muir DF, Schultz GS (2002) Ratios of activated matrix metalloproteinase-9 to tissue inhibitor of matrix metalloproteinase-1 in wound fluids are inversely correlated with healing of pressure ulcers. Wound Repair Regen 10: 26-37.

Lehmann HC, Chen W, Borzan J, Mankowski JL, Höke (2011) A Mitochondrial dysfunction in distal axons contributes to human immunodeficiency virus sensory neuropathy. Ann Neurol 69: 100-110.

Li Y, SongYH, Li F, Yang T, Lu YW, Geng YJ (2009) MicroRNA-221 regulates high glucose-induced endothelial dysfunction. Biochem Biophys Res Commun 381: 81-83.

Lipsky BA, Berendt AR, Cornia PB, Pile JC, Peters EJ, Armstrong DG, Deery HG, Embil JM, Joseph WS, Karchmer AW, Pinzur MS, Senneville E, Infectious Diseases Society of America (2012) Executive summary 2012: Infectious Diseases Society of America practice guideline for the diagnosis and treatment of diabetic foot infections. Clin Inect Dis 54: 1679-1684.

Lusis AJ (2000) Atherosclerosis. Nature 407: 233-241.

Lu H, Kraut D, Gerstenfeld LC, Graves DT (2003) Diabetes interferes with the bone formation by affecting the expression of transcription factors that regulate osteoblast differentiation. Endocrinology 144 346-352.

Mabilleau G, Petrova NL, Edmonds ME, Sabokbar A (2008) Increased osteoclastic activity in acute Charcot osteoarthropathy: the role of receptor activator of nuclear factor kappa B ligand. Diabetologia 51: 1035-1040.

Madhyastha R, Madhyastha H, Nakajima Y, Omura S, Maruyama M (2011) MicroRNA signature in diabetic wound healing: promotive role of miR-21 in fibroblast migration. Int Wound J 9: 355-361.

Maskos K (2004) Crystal structures of MMPs in complex in complex with physiological and pharmacological inhibitors. Biochimie 87: 249263.

McCawley LJ, Matrisian LM. (2001) Matrix metalloproteinases: they're not just for matrix anymore! Curr Opin Cell Biol 13: 534-540.

Nathan DM, Cleary PA, Backlund JY, Genuth SM, Lachin JM, Orchard TJ, Raskin P, Zinman B; Diabetes Control and Complications Trial/Epidemiology of Diabetes Interventions and Complications (DCCT/EDIC) Study Research Group (2005) Intensive diabetes treatment and cardiovascular disease in patients with type 1 diabetes. N Engl J Med 353: 2643-2653.

Nicholson SE, Metcalf D, Sprigg NS, Columbus R, Walker F, Silva A, Cary D, Willson TA, Zhang JG, Hilton DJ. Warrenn A, Nicos AN (2005). Suppressor of cytokine signaling (SOCS)-5 is a potential negative regulator of epidermal growth factor signaling. Proc Nat Acad Sci USA 102: 2328-2333.

Pałka J, Sobolewski K, Bańkowski E (1991) Cathepsin D inhibitor from potato reverses nhibition of collagen biosynthesis in wounded skin of rats with experimental diabetes. Acta Biochim Pol 38: 115118.

Pirola L, Balcerczyk A, Okabe J, El-Osta A (2010) Epigenetic phenomena linked to diabetic complications. Nat Rev Endocrinol 6: 665-675.

Pitocco D, Zelano G, Gioffrè G, Di Stasio E, Zaccardi F, Martini F, Musella T, Scavone G, Galli M, Caputo S, Mancini L, Ghirlanda G (2009) Association Between Osteoprotegerin G1181C and T245G Polymorphisms and Diabetic Charcot Neuroarthropathy. Diabetes Care 32: 1694-1697.

Pop-Busui R, Low PA, Waberski BH, Martin CL, Albers JW, Feldman EL, Sommer C, Cleary PA, Lachin JM, Herman WH; DCCT/EDIC Research Group (2009) Effects of prior intensive insulin therapy on cardiac autonomic nervous system function in type 1 diabetes mellitus: the Diabetes Control and Complications Trial/Epidemiology of Diabetes Interventions and Complications study (DCCT/EDIC). Circulation 119: 2886-2893.

Rajbhandari SM, Jenkins RC, Davies C, Tesfaye S (2002) Charcot neuroarthropathy in diabetes mellitus. Diabetologia 45: 1085-1096.

Riddel DR, Owen JS (1999) Nitric oxide and platelet aggregation. Vitam Horm 57: 25-48.

Rogers LC, Frykberg RG, Armstrong DG, Boulton AJ, Edmonds M, Van GH, Hartemann A, Game F, Jeffcoate W, Jirkovska A, Jude E, Morbach S, Morrison WB, Pinzur M, Pitocco D, Sanders L, Wukich DK, Uccioli L (2011) The Charcot foot in diabetes. Diabetes Care 34: 2123-2129.

Roy S, Sala R, Cagliero E, Lorenzi M (1990) Overexpression of fibronectin induced by diabetes or high glucose: phenomenon with a memory. Proc Natl Acad Sci USA 87: 404-408.
Santana RB, Xu L, Chase HB, Amar S, Graves DT, Trackman PC (2003) A role for advanced glycation end products in diminished bone healing in type 1 diabetes. Diabetes 52: 1502-1510.

Santini D, Schiavon G, Vincenzi B, Gaeta L, Pantano F, Russo A, Ortega C, Porta C, Galluzzo S, Armento G, La Verde N, Caroti C, Treilleux I, Ruggiero A,Perrone G, Addeo R, Clezardin P, Muda AO, Tonini G (2011) Receptor activator of NF-xB (RANK) expression in primary tumors associates with bone metastasis occurrence in breast cancer patients. PLoS One 6: e19234.

Scelsi R, Lotta S, Sverzellati S, Poggi P (2005) Morphological alterations of microvasculature and neoangiogenesis in the pressure ulcers repair in paraplegics. Basic Appl Myol 15: 203-208.

Singh N, Armstrong DG, Lipsky BA (2005) Preventing foot ulcers in patients with diabetes. Jama 293: 217-228.

Siqueira MF, Li J, Chehab L, Desta T, Chino T, Krothpali N, Behl Y, Alikhani M, Yang J, Braasch C, Graves DT. (2010) Impaired wound healing in mouse models of diabetes is mediated by TNF-alpha dysregulation and associated with enhanced activation of forkhead box O1 (FOXO1). Diabetologia 53: 378-388.

Slotkin RK, Martienssen R (2007) Transposable elements and the epigenetic regulation of the genome. Nat Rev Genet 8: 272-285.

Stojadinovic O, Pastar I, Gordon KA, Tomic-Canic M (2012) Physiology and Pathophysiology of Wound Healing in Diabetes. In The Diabetic Foot. Veves A, Giurini JM, LoGerfo FW eds, pp 127-149. Humana Press Inc. New York.

Tang SY, Vashishth D (2010) Non-enzymatic glycation alters microdamage formation in human cancellous bone. Bone 46: 148-154.

Tesfaye S, Chaturvedi N, Eaton SE, Ward JD, Manes C, Ionescu-Tirgoviste C, Witte DR, Fuller JH EURODIAB Prospective Complications Study Group (2005) Vascular risk factors and diabetic neuropathy. $N$ Engl J Med 352: 341-350.

Turner RC (1998) The U.K. Prospective Diabetes Study. A review. Diabetes Care 21: C35-C38.

Tyndall WA, Beam HA, Zarro C, O'Connor JP, Lin SS (2003) Decreased platelet derived growth factor expression during fracture healing in diabetic animals. Clin Orthop Relat Res 408: 319-330.

Unoki H, Takahashi A, Kawaguchi T, Hara K, Horikoshi M, Andersen G, Ng DP, Holmkvist J, Borch-Johnsen K, Jørgensen T, Sandbaek A, Lauritzen T, Hansen T, Nurbaya S, Tsunoda T, Kubo M, Babazono T, Hirose H, Hayashi M, Iwamoto Y, Kashiwagi A, Kaku K, Kawamori R, Tai ES, Pedersen O, Kamatani N, Kadowaki T, Kikkawa R, Nakamura Y, Maeda S (2008) SNPs in KCNQ1 are associated with susceptibility to type 2 diabetes in East Asian and European populations. Nature Genet 40: 1098-1102.

Werner S, Breeden M, Hübner G, Greenhalgh DG, Longaker MT (1994) Induction of keratinocyte growth factor expression is reduced and delayed during wound healing in the genetically diabetic mouse. I Invest Dermatol 103: 469-473.

Valcourt U, Merle B, Gineyts E, Viguet-Carrin S, Delmas PD, Garnero P (2007) Non-enzymatic glycation of bone collagen modifies osteoclastic activity and differentiation. J Biol Chem 282: 5691-5703.

Vasaquez V, Henderson S (2010) Charcot foot? Charcot arthropathy caused by lisfrane fracture-dislocation in a diabetic. West J Emerg Med 11: 146-147.

Vestergaard P, Rejnmark L, Mosekilde L (2005) Relative fracture risk in patients with diabetes mellitus, and the impact of insulin and oral antidiabetic medication on relative fracture risk. Diabetologia 48: 1292-1299.

Vestergaard P (2007) Discrepancies in bone mineral density and fracture risk in patients with type 1 and type 2 diabetes - a metaanalysis. Osteoporos Int 18: 427-444.

Visse R, Nagase H. (2003) Matrix metalloproteinases and tissue inhibitors of metalloproteinases: structure, function, and biochemistry. Circ Res 92: 827-839.

Xu J, Wu W, Zhang L, Dorset-Martin W, Morris WM, Mitchell ME, Liechty KW (2012) The Role of microRNA-146a in the pathogenesis of the diabetic wound-healing impairment correction with mesenchymal stem cell treatment. Diabetes 61: 2906-2912

Yamagishi N, Nakayama K, Wakatsuki T, Hatayama T (2001) Characteristic changes of stress protein expression in streptozotocin-induced diabetic rats. Life Sci 69: 2603-2609.

Yasuda K, Miyake K, Horikawa Y, Hara K, Osawa H, Furuta H, Hirota $\mathrm{Y}$, Mori H, Jonsson A, Sato Y, Yamagata K, Hinokio Y, Wang HY, Tanahashi T, Nakamura N, Oka Y, Iwasaki N, Iwamoto Y, Yamada Y, Seino Y, Maegawa H, Kashiwagi A, Takeda J, Maeda E, Shin HD, Cho YM, Park KS, Lee HK, Ng MC, Ma RC, So WY, Chan JC, Lyssenko V Tuomi T, Nilsson P Groop L, Kamatani N, Sekine A, Nakamura Y, Yamamoto K, Yoshida T, Tokunaga K, Itakura M, Makino H, Nanjo K, Kadowaki T, Kasuga M (2008) Variants in KCNQ1 are associated with susceptibility to type 2 diabetes mellitus. Nature Genet 40: 1092-1097.

Zhang K, McQuibban GA, Silva C, Butler GS, Johnston JB, Holden J, Clark-Lewis I, Overall CM, Power C (2003) HIV-induced metalloproteinase processing of the chemokine stromal cell derived factor-1 causes neurodegeneration. Nat Neurosci 6: 1064-1071. 